\title{
Wayang Jawa Timuran Lakon Gandamana Luweng (Kajian Struktur Dan Makna)
}

\author{
ANDINI SHINTA KURNIAWATI \\ Program Studi Pendidikan Seni Budaya, Pascasarjana Universitas Negeri Surabaya \\ E-mail : andinishinta96@gmail.com
}

\begin{abstract}
Wayang, sebagai salah satu bentuk kesenian klasik tradisional yang oleh pecintanya dikatakan mempunyai nilai adiluhung, banyak mempengaruhi tata nilai kehidupan Jawa khususnya dan masyarakat pada umumnya. Orang Jawa begitu percaya adanya perlambang, simbolisasi ataupun filsafat hidup yang berupa mitos pada satu lakon wayang.Salah satu lakon wayang yang cukup menarik perhatian adalah lakon wayang dengan judul "Gandamana Luweng". Pokok permasalahan yang dikaji dalam penulisan ini adalah (1) Bagaimana struktur lakon Gandamana Luweng, (2) Bagaimana makna simbolik lakon Gandamana Luweng. zTujuan penulisan ini yaitu menganalisa dan mendeskripsikan struktur lakon dan makna simbolik lakon Gandamana Luweng.Penelitian ini menggunakan desain penelitian kualitatif dengan pendekatan fenomnologis empiris. Subjek utama dalam penelitian ini adalah Ki Pringgo Jati Rahmanu, sedangkan pengumpulan data diperoleh dengan pengamatan, wawancara, studi dokumen, dokumentasi. Analisis data dilakukan melalui reduksi data, penyajian data, dan penarikan kesimpulan. Pemerksaan keabsahan data menggunakan informan review dan triangulasi data (sumber dan teknik). Hasil penelitian ini menunjukkan bahwa struktur lakon Gandamana Luweng terdiri atas sinopsis, penjabaran lakon, penokohan, alur, setting, dan tema cerita.Lakon Gandamana Luweng ini memiliki makna bahwa jika dalam suatu Negara para rakyatnya bermoral lemah tidak mempunyai kekuatan dan keberanian apalagi kesadaran apa arti hidup ini maka hancurlah Negara itu.Dari data tersebut dapat disimpulkan bahwa Lakon Gandamana Luweng memiliki struktur lakon cukup menarik yang dikemas dalam durasi tampilan 60 menit, sedangkan dengan adanya makna simbolik yang terkandung diharapkan para pelaku hidup ini akan sadar tentang pentingnya saling mengerti, menyadari tentang hidup dan kehidupan di dunia.
\end{abstract}

Kata kunci: wayang, lakon, gandamana luweng

\section{Wayang Jawa Timuran Lakon Gandamana Luweng (Study Of Structure And Meaning)}

Shadow Puppettry, as one of the traditional classical art form that by the lover is said to hold in high value, hold much affect to the values of life of Java in particular and its society in general. The Javanese are very confident in the use of symbols. Symbols and philosophies of life that are manifest in one myth in one puppet play. One of the puppet plays that attract attention is the wayang play entitled "Gandamana Luweng". The main issues studied in this book are (1) How Gandamana Luweng play is structured, (2) The symbolic meaning of Gadamana Luweng play. The purpose of this paper is to analyze and describe the structure of the play and the symbolic implications of the play Gandamana Luweng. This research uses qualitative research design with empirical phenomenological approach. The main subject in this study is Ki Pringgo Jati Rahmanu, while data collection is obtained with observation, interview, document study, documentation. Data analysis is done through by data reduction, presentation data, and conclusion. The validity of data is checked using using informant review and triangulation of data (source and technique). The results of this study indicate the structure of the Gandamana Luweng play consists of synopsis, description of the play, characterization, plot, setting, and theme of the story. This Gandamana Luweng play has the meaning if country's people possess weak moral, no strength and courage let alone awareness as to what this life means, then the country is destroyed. From these data can be concluded Gandamana Luweng shadow puppet play holdss a fascinating structure that comprises a 60 minute view duration, where the symbolic meanings intentions are expected that these actors will be aware of understanding each other, conscious about life and life in the world.

Keywords : puppet, play, gandamana luweng

Proses Review : 2 - 19 Januari 2018, Dinyatakan Lolos: 22 Januari 2018 


\section{PENDAHULUAN}

Jawa Timur sebagai salah satu wilayah yang kaya dengan seni dan budaya, berusaha untuk menggali, melestarikan, serta mengembangkan khasanah budaya yang beraneka ragam. Usaha pelestarian yang tidak ternilai harganya pada dasarnya mengandung manfaat yang sangat berarti bagi kelangsungan hidup seni budaya itu sendiri. Kesenian merupakan unsur yang paling utama dari kebudayaan nasional. Kedudukan kesenian yang sangat penting itu menuntut pengembangan yang selaras dengan usaha pengembangan kebudayaan nasional, karena pada dasarnya kebudayaan nasional adalah kesatuan besar yang terdiri dari berbagai macam budaya daerah, termasuk di dalamnya kesenian daerah ataupun kesenian tradisional.

Salah satu kesenian tradisional yang hidup dan berkembang di lingkungan masyarakat di Jawa Timur, misalnya kesenian wayang kulit. Dalam Bahasa Jawa, kata wayang berarti "bayangan". Jika ditinjau dari arti filsafatnya "wayang" dapat diartikan sebagai bayangan atau merupakan pencerminan dari sifat-sifat yang ada dalam jiwa manusia. Wayang, sebagai salah satu bentuk kesenian klasik tradisional yang oleh pecintanya dikatakan mempunyai nilai adiluhung, banyak mempengaruhi tata nilai kehidupan Jawa khususnya dan masyarakat pada umumnya.

Cerita, sangat penting dalam pertunjukan wayang kulit. Begitupun orang Jawa begitu percaya adanya perlambang, simbolisasi ataupun filsafat hidup yang berupa mitos pada satu lakon wayang (Sumaryono, 2007:184). Salah satu lakon wayang yang cukup menarik perhatian penulis adalah lakon wayang dengan judul "Gandamana Luweng". Lakon ini disajikan oleh Ki Pringgo Jati Rahmanu, dalang muda kelahiran tahun 1995 asal Sidoarjo dalam Festival Dalang Muda Nasional tanggal 17 sampai 20 November 2016 di Jakarta. Dengan lakon yang dibawakannya ini, Pringgo berhasil mengharumkan nama Jawa Timur dalam festival nasional dan menjadi penyaji lakon terbaik. Penyajian lakon Gandamana Luweng berdurasi kurang lebih 60 menit ini, mempunyai naskah cerita yang didalamnya mengandung pesan atau nilai-nilai ajaran hidup bagi masyarakat.

Melihat wayang yang berisi nilai-nilai ajaran hidup dan wayang sebagai tuntunan, maka tidaklah aneh jika wayang dijadikan sebagai media pendidikan serta dijadikan tuntunan hidup, khususnya orang Jawa. Ada yang menarik lagi yang membuat wayang dipilih sebagai salah satu objek kajian, yaitu karena minat generasi muda terhadap apresiasi sastra khusus- nya wayang ini sangat rendah. Mereka menganggap bahwa pertunjukan wayang itu adalah pertunjukkan wayang kuno. Apalagi bahasa yang digunakan pun biasanya sangat susah dipahami oleh generasi muda. Dari penjelasan yang telah dijabarkan sebelumnya, maka penulis tertarik untuk mengkaji tulisan ini dalam bentuk artikel yang berjudul "Wayang Jawa Timuran Lakon Gandamana Luweng" dengan fokus penelitian terletak pada struktur lakon dan makna simbolik. dengan kajian teori dan konsep yang terdiri atas konsep drama turgi, konsep tokoh, teori semiotik, dan konsep makna simbolik.

\section{PEMBAHASAN}

\section{Struktur Lakon Gandamana Luweng}

\section{Sinopsis Lakon atau Cerita}

Gandamana seorang ksatria sejati penuh lika liku dalam hidupnya. Gandamana selalu menegakkan kebenaran tak peduli siapapun pasti dimusnahkan musuh atau saudara, teman atau tetangga. Yang dibicarakan adalah kebenaran, dan kebatilan adalah musuhnya. Kadang kejahatan telah terhias rapi dalam kedok dan bungkus untuk menyembunyikan keasliannya. Tetapi Gandamana tak mengenal basa basi. Berani karena benar dan takut karena salah. Perjuangan Gandamanadalam menegakkan kebenaran ibarat air yang mengalir tak terhenti yang merusak tatanan harus ditiadakan.

\section{Penjabaran Lakon atau Cerita}

Katon goreh nyleneh lagak lugon lan lageyane si Haryo Suman, amenggalih kamulyan gesangipun ing tembe. Gia Suman sowan ngarsane Prabu Pandhu nggawe rekadaya murih Patih Gandamana lengser saka palungguhan kepatihan ing Negara Ngastina. Kanti layang pinaringan Prabu Kala Trembaka den owahi wujud layang penantang tumrap Negara Ngastina lan Prabu Pandhu, kagiat Prabu Pandhu Dewayana den utus Patih Gandamana njatakno ponang kintaka menyang ngarsaning Prabu Kala Trembaka ing Negara Pringgodani. Ing kono Suman uga nyuwun pamit medhal paseban njawi den dhisiki lakune Gandamana menyang Negara Pringgodani, kepanggih Prabu Kala Trembaka, Suman ngedu kumbo yen to layang saka Prabu Kala Trembaka ora ditampa dening Prabu Pandhu.

Awit telung pasewakan iki Prabu Trembaka ora prapteng Negara Ngastina, Prabu Trembaka sing didakwa bakal medhot taline kekadhangan. Malah keporo wus merintah Patih Gandamana ijen tanpa wadyabala bakal ngasorno kawibawaane Prabu Trembaka. Merga salah tompo ungkasane rembag, 
konco bakah antarane raden arimba lan Patih Gandamana. Raden Arimba kasor ing yudo kepranggul Haryo Suman, Raden Arimba ra trimo banjur dipenggak marang Haryo Suman. Nek kalah okol nggunakno akal murih patine Gandamana ing Negara Pringgodani kudu direkadaya, jeneng sira Arimba enggalo ngutus wadyabala Pringgodani gawe luwengan banjur ditutup nganggo gegodongan. Majune Reden Arimba mancing Patih Gandamana supaya nguber playune, lena sang Gandamana kacemplung sajroning luweng, banjur den krocok watu lawan wadyabala Pringgodani.

Raden Suman bungah penggalihe awit gandamana tumekeng lampus, Raden Suman wangsul ing Gajah Hoya nyuwun pangestu menyang Dewi Gendari lan Adipati Drestaratsa yen to deweke siap nglungguhi komplange kepatihan Negara Ngastina. Gandamana kang lemah dayane gio ngerapal aji sulung jaya yen ngasor ing yudo den sumbari musuh bisa santosa maneh kekuatane, watu den pancal mbledos saka jero luweng, duko sang Gandamana. Den trajang prajurit Pringgodani, majune Prabu Trembaka tandhing yudo klawan Patih Gandamana, den ajar nanging Patih Gandamana ora males babar pisan malah arso atur sembah marang Prabu Trembaka, lajeng ngedalaken nawala. Ngerti yen surat iki ono sing ngadu kumbo supaya Prabu Kala Trembaka lan Prabu Pandhu congkrah, Gandamana nyuwun pamit. Ngupadi sinten ingkang cumantaka ngowahi isine nawala.

Gantio cinarito ingkang wonten kadipaten Gajah Hoya, Dewi Gendari lan Patih Drestarasta kehadep ingkang rayi Haryo Suman. Dereng pantoro dangu imbal wacana den saut Haryo Suman kelawan Patih Gandamana den ajar nganti cuklek bebalunge nganti cacat wujude. Ngerti Gandamana tego mrawasa Haryo Suman, Dewi Gendari matur ing ngarsane rayi Prabu Pandhu, abot sedulur opo abot patih, nek abot sedulur patih gandamana kudu dipidana, ning nek abot patih becik aku bali menyang plasa jenar.

Lajeng Prabu Pandhu mapak lakune Gandamana njabel palungguhane saka kepatihan bakal den ganti kelawan Haryo Suman lan Gandamana den tundung saka Negara Ngastina ojo pisan-pisan bali sepet aku nyawang Gandamana kang nduweni watak tego mentolo. Patih Gandamana nompo ucape Prabu Pandu lan ora bakal bali lan ngaton saka Negara Ngastina, nanging layang kang wes direkadaya mau den aturno marang Parbu pandu den cethakno yen to laying iku direkadaya kelawan Haryo Suman supaya ndadekno congkrah ing natarane sedulur Prabu Pandu dan Kala Trembaka. Getun eduwung Prabu Pandu ndulu nawala kang direkadaya kelawan Haryo Suman, Suman lan Dewi Gendari bungah penggalihe mbesuk yen patihe Haryo Suman tertentu sata Kurawa bakal urip mulyo, jaman saiki yen ora direwangi tipu daya ndadung alus jala sutra ora bakal oleh opo-opo, jamane jaman edan yen ora edan ora keduman.

Terlihat tidak seperti biasanya si Haryo Suman yang sedang memikirkan masa depan kehidupannya. Berangkatlah Suman ke hadapan Prabu Pandhu dengan segala kejulikannya (tipu daya) mengadu domba Patih Gandamana supaya jatuh jabatannya sebagai patih di Negara Ngastina. Dengan sebuah surat pemberian Prabu Kala Trembaka diubah berupa surat penantang untuk Negara Ngastina dan Prabu Pandhu, diutuslah Patih Gandamana untuk menyatakan langsung surat tersebut ke hadapan Prabu Kala Trembaka di Negara Pringgodani. Disitu Raden Suman juga ijin pamit keluar kraton didahului jalannya Patih Gandamana yang hendak ke Negara Pringgodani dan bertemu dengan Prabu Kala Trembaka, Raden Suman menipu bawasannya surat dari Prabu Trembaka tidak diterima oleh Prabu Pandhu.

Sebab tiga kali pertemuan ini Prabu Trembaka tidak hadir di Negara Ngastina, Prabu Trembaka yang disebut akan memutuskan tali persaudaraan. Malah sudah memerintah Patih Gandamana sendiri tanpa prajurit yang akan mengalahkan kekuasaan Prabu Trembaka. Marah Prabu Trembaka memerintah putranya Raden Arimba untuk menghadang Patih Gandamana. Karena kesalahpahaman terjadilah peperangan antara Raden Arimba dengan Patih Gandamana. Raden Arimba kalah dalam peperangan melawan Patih Gandamana, Raden Arimba tidak terima, lalu dicegah oleh Haryo Suman. Kalau kalah otot menggunakan akal supaya mati Gandamana di Negara Pringgodani harus dijebak, kamu Raden Arimba cepat memberi perintah kepada prajurit Pringgodani untuk membuat sumur yang ditutup cengan dedaunan. Majunya Raden Arimba memancing Gandamana supaya mengejar larinya, namun karena ketidakwaspadaan Gandamana membuat dirinya terjebak kedalam sumur lalu ditutup bebatuan oleh prajurit Pringgodani

Raden Suman senang hatinya karena Gndamana menemui ajalnya, Raden Suman pulang ke kadipaten Gajah Hoya meminta restu kepada Dewi Gendari dan Adipati Drestarastra bersiap untuk menjadi patih di Negara Ngastina. Gandamana yang lemah dayanya langsung menggunakan aji sulung jaya yang efeknya ketika kalah berperang jika diremehkan lawan bisa pulih kembali kekuatannya, batu ditendang ,meledak dari dalam sumur, marah Gandamana. Dihabisi Prajurit pringgodani, majulah Prabu Trembaka perang melawan Patih Gandamana, dihajar oleh Prabu Trembaka tapi Gandamana tidak membalas sama sekali, malah mengaturkan sembah kepada Prabu Trembaka lalu mengeluarkan surat. Begitu tahu surat ini ada yang merekayasa dan mengadu domba antara 
Prabu Trembaka dan Prabu Pandu supaya tidak rukun pamitlah sang Gandamana mencari orang yang telah berani menghasut melalui surat tersebut.

Berganti cerita yang berada di kadipaten Gajah Hoya, Dewi Gendari dan Patih Drestarata didatangi oleh adiknya Haryo Suman. Belum sampai lama berbicara disahutlah Haryo Suman dipukuli oleh Patih Gandamana sampai patah tulangnya hingga cacat tubuhnya. Mengetahui Patih Gandamana tega menghajar Haryo Suman, Dewi Gendari menemui Prabu Pandhu ,mengatakan mementingkan saudara atau patih, jika peduli kepada saudara Patih gandamana harus dihukum seberat-beratnya, kalau lebih peduli kepada patih lebih baik aku pulang ke Plasa Jenar.

Lalu Prabu Pandu menyusul Patih Gandamana mencabut jabatannya dari kepatihan Negara Ngastina akan diganti oleh Haryo Suman dan Gandamana diusir dari Negara Ngastina, jangan sekali-kali kembali benci melihat Patih Gandamana yang mempunyai watak tega. Patih Gandamana menerima ucap dari Prabu Pandu dan tidak akan kembali lebih-lebih terlihat di Negara ngastina, tetapi surat yang sudah dirubah oleh Haryo Suman dikembalikan pada Prabu Pandhu dan dijelaskan kalau surat tadi diubah oleh Haryo Suman supaya terjadi congkrah antara Prabu Pandu dan Prabu Kala Trembaka. Menyesal sekali Prabu Pandu melihat surat yang dirubah oleh Haryo Suman, Suman dan Dewi Gendari senang sekali hatinya besok jika patihnya Haryo Suman pasti keluarga Kurawa akan hidup mulya, jaman sekarang kalau tidak menggunakan tipu daya tidak akan dapat apaapa, jamannya jaman gila, jika tidak gila tidak dapat apa-apa

\section{Penokohan}

Dramaturgi menurut Harymawan (1986:1) adalah ajaran tentang masalah hukum, dan konvensi drama. Ada orang yang menganggap drama sebagai lakon yang menyedihkan, sehingga dapat diartikan sebagai sandiwara tragedy. Kita sering mendengar istilah-istilah tokoh dan penokohan, watak dan perwatakan, atau karakter dan karakterisisasi secara bergantian dengan pengertian yang hampir sama dalam pembicaraan sebuah karya. Istialh-istilah tersebut sebenarnya tidak persis sama dan dipergunakan dalam pengertian yang berbeda walau ada sinonim dalam istilah-istilah tersebut. Menurut Nurgiyanto (2002) istilah tokoh menunjuk pada orangnya atau pelaku cerita. Tokoh adalah individu rekaan yang mengalami peristiwa di dalam berbagai peristiwa cerita. Watak, perwatakan, dan karakter menunjuk pada sifat dan sikap para tokoh.

Klasifikasi jenis-jenis tokoh ada bermacam-macam.
Berdasarkan peran tokoh it dalam cerita, terdapat tokoh sentral dan tokoh tokoh bawahan atau tokoh utama dan tokoh pembantu. Berdasarkan pembangunan konflik cerita, terdapat tokoh protagonist dan tokoh antagonis. Tokoh protagonist dan antagonis termasuk tokoh sentral. Disamping itu terdapat juga tokoh wirayawan dan anti wirawan yang biasanya menggeser kedudukan tokoh antagonis dan tokoh protagonis. (Panuti Sujiman, dalam Nurgiantoro 2002). Secara keseluruhan tokoh terdiri atas sepuluh ragam: tokoh utama, tokoh tambahan, tokoh protagonist, tokoh antagonis, tokoh sederhana, tokoh bulat. tokoh statis, tokoh berkembang, tokoh tipikal, tokoh netral.

Bila ditinjau dari judul lakonnya, tentu tokoh utama dalam cerita ini adalah Patih Gandamana. Selain tokoh utama tersebut juga terdapat tokoh-tokoh tambahan seperti Patih Haryo Suman, Prabu Pandhu, Prabu Kala Trembaka, Raden Arimba, Dewi Gendari, Adipati Drestarasta. Berikut ini akan dijelaskan penokohan dalam lakon wayang Gandamana luweng. Penyajian data diperoleh dari penggambaran secara langsung. Perwatakan yang dimiliki oleh para tokoh itu sangat berbeda antara tokoh satu dengan yang lain. Hal itu bisa dilihat dari ucapan atau perilaku yang dilakukan oleh para tokoh tersebut.

\section{Alur Cerita}

Di dalam lakon Gandamana Luweng alur yang digunakan adalah alur campuran dimana alur campuran merupakan suatu perpaduan antara alur kronologis dan alur tidak kronologis. Proses penceritaannya dapat dimasukan ke dalam beberapa tahap yaitu pada tahap pemaparan, tahap penggawatan, tahap penanjakan, tahap klimaks atau puncak, dan tahap peleraian. Berikut merupakan penjelasannya: 1) Tahap Pemaparan, tahap ini merupakan tahap pembukaan cerita, pemberian informasi awal. Tahapan ini berfungsi sebagai landasan dan tumpuan cerita yang akan dikisahkan dalam tahapan berikutnya. Tahap pemaparan di dalam lakon Gandaman Luweng dapat diketahui melalui bagian prolog drama dan babak I. Di dalam prolog drama dan babak I drama tersebut bermula dari keinginan Patih Haryo Suman untuk mengadu domba Patih Gandamana supaya jatuh jabatannya sebagai patih di Negara Ngastina. 2) Tahap Penggawatan, tahap kemunculan konflik. Dari tahapan ini konflik akan berkembang atau dikembangakan menjadi konflik-konflik pada tahapan berikutnya. Dalam lakon Gandamana Luweng, tahap penggawatan ada beberapa permasalahan antara tokoh-tokohnya, dimana permasalahan dan konflik tersebut merupakan pembangun tahap penggawatan di dalam lakon ini. Tahap penggawatan sudah mulai nampak pada adegan Patih Haryo Suman menipu bawasannya surat dari Prabu Trembaka tidak diterima oleh Prabu Pand- 
Tabel 1.

\begin{tabular}{|c|c|c|c|}
\hline Tokoh & Watak & Indikator & Terjemahan \\
\hline $\begin{array}{l}\text { Patih Ganda- } \\
\text { mana }\end{array}$ & $\begin{array}{l}\text { Pemberani, tidak } \\
\text { mudah menyerah }\end{array}$ & $\begin{array}{l}\text { Gandamana kang lemah } \\
\text { dayane gio ngerapal aji } \\
\text { sulung jaya yen ngasor } \\
\text { ing yudo den sumbari } \\
\text { musuh bisa santosa } \\
\text { maneh kekuatane, watu } \\
\text { den pancal mbledos saka } \\
\text { jero luweng, }\end{array}$ & $\begin{array}{l}\text { Gandamana yang lemah } \\
\text { dayanya langsung } \\
\text { menggunakan aji sulung } \\
\text { jaya yang efeknya keti- } \\
\text { ka kalah berperang jika } \\
\text { diremehkan lawan bisa } \\
\text { pulih kembali kekua- } \\
\text { tannya, batu ditendang } \\
\text {,meledak dari alam } \\
\text { sumur, }\end{array}$ \\
\hline $\begin{array}{l}\text { Patih Haryo } \\
\text { Suman }\end{array}$ & Licik, penipu & $\begin{array}{l}\text { - Gia Suman sowan } \\
\text { ngarsane Prabu Pandhu } \\
\text { nggawe rekadaya murih } \\
\text { Patih Gandamana lengs- } \\
\text { er saka palungguhan } \\
\text { kepatihan ing Negara } \\
\text { Ngastina. } \\
\\
\text { - Suman ngedu kumbo } \\
\text { yen to layang saka Prabu } \\
\text { Kala Trembaka ora } \\
\text { ditampa dening Prabu } \\
\text { Pandhu }\end{array}$ & $\begin{array}{l}\text { - Berangkatlah Su- } \\
\text { man ke hadapan Prabu } \\
\text { Pandhu dengan segala } \\
\text { kejulikannya (tipu daya) } \\
\text { mengadu domba Patih } \\
\text { Gandamana supaya } \\
\text { jatuh jabatannya sebagai } \\
\text { patih di Negara Ngasti- } \\
\text { na } \\
\text {-Raden Suman menipu } \\
\text { bawasannya surat dari } \\
\text { Prabu trembaka tidak } \\
\text { diterima oleh Prabu } \\
\text { Pandhu }\end{array}$ \\
\hline Prabu Pandhu & $\begin{array}{l}\text { Mudah dipen- } \\
\text { garuhi }\end{array}$ & $\begin{array}{l}\text { Prabu Pandhu mapak } \\
\text { lakune Gandamana } \\
\text { njabel palungguhane } \\
\text { saka kepatihan bakal } \\
\text { den ganti kelawan Haryo } \\
\text { Suman }\end{array}$ & $\begin{array}{l}\text { Prabu Pandu menyu- } \\
\text { sul Patih Gandamana } \\
\text { mencabut jabatannya } \\
\text { dari kepatihan Negara } \\
\text { Ngastina akan diganti } \\
\text { oleh Haryo Suman }\end{array}$ \\
\hline $\begin{array}{l}\text { Prabu Kala } \\
\text { Trembaka }\end{array}$ & Pemarah & $\begin{array}{l}\text { Duka Prabu Trembaka } \\
\text { ngutus putrane Raden } \\
\text { Arimba supaya nyegat } \\
\text { lakune Patih Gandamana }\end{array}$ & $\begin{array}{l}\text { Marah Prabu Trembaka } \\
\text { memerintah putranya } \\
\text { Raden Arimba untuk } \\
\text { menghadang Patih Gan- } \\
\text { damana }\end{array}$ \\
\hline
\end{tabular}




\begin{tabular}{|c|c|c|c|}
\hline Raden Arimba & Licik & $\begin{array}{l}\text { Majune Reden Arimba } \\
\text { mancing Patih Ganda- } \\
\text { mana supaya nguber } \\
\text { playune, lena sang } \\
\text { Gandamana kacemplung } \\
\text { sajroning luweng, banjur } \\
\text { den krocok watu lawan } \\
\text { wadyabala Pringgodani }\end{array}$ & $\begin{array}{l}\text { Majunya Raden Arimba } \\
\text { memancing Gandama- } \\
\text { na supaya mengejar } \\
\text { larinya, namun kare- } \\
\text { na ketidakwaspadaan } \\
\text { Gandamana membuat } \\
\text { dirinya terjebak keda- } \\
\text { lam sumur lalu ditutup } \\
\text { bebatuan oleh prajurit } \\
\text { Pringgodani }\end{array}$ \\
\hline Dewi Gendari & Licik, tidak tegaan & $\begin{array}{l}\text {-Suman lan Dewi } \\
\text { Gendari bungah pengga- } \\
\text { lihe mbesuk yen patihe } \\
\text { Haryo Suman tertentu } \\
\text { sata Kurawa bakal urip } \\
\text { mulyo } \\
\text { - Dewi Gendari matur } \\
\text { ing ngarsane rayi Prabu } \\
\text { Pandhu, abot sedulur } \\
\text { opo abot patih, nek abot } \\
\text { sedulur patih gandamana } \\
\text { kudu dipidana, }\end{array}$ & $\begin{array}{l}\text {-Suman dan Dewi } \\
\text { Gendari senang seka- } \\
\text { li hatinya besok jika } \\
\text { patihnya Haryo Suman } \\
\text { pasti keluarga Kurawa } \\
\text { akan hidup mulya } \\
\\
\text { - Dewi Gendari me- } \\
\text { nemui Prabu Pandhu } \\
\text {,mengatakan mement- } \\
\text { ingkan saudara atau } \\
\text { patih, jika peduli kepada } \\
\text { saudara Patih ganda- } \\
\text { mana harus dihukum } \\
\text { seberat-beratnya }\end{array}$ \\
\hline
\end{tabular}

hu. 3) Tahap Penanjakan, tahap ini merupakan tahap peningkatan konflik dimana konflik yang muncul dalam pada tahapan sebelumnya semakin berkembang kadar intensitasnya. Peristiwa-peristiwa dramatik yang menjadi inti cerita semakin mencekam, menegangkan dan mengarah ke arah klimaks, dan tidak dapat dihindari. Dalam lakon Gandamana Luweng tahap penanjakan mulai muncul ketika adegan majunya Raden Arimba memancing Gandamana supaya mengejar larinya, namun karena ketidakwaspadaan Gandamana membuat dirinya terjebak kedalam sumur lalu ditutup bebatuan oleh prajurit Pringgodani. 4) Tahap Klimaks, Tahap ini merupakan merupakan tahap yang menunjukan konflik dan pertentangan-pertentangan yang terjadi ditimpakan kepada para tokoh cerita mencapai titik intensitas puncak. Tahap klimaks atau puncak dalam lakon Gandamana Luweng terjadi ketika cerita telah berada di kadipaten Gajah Hoya, Dewi Gendari dan Patih Drestarata didatangi oleh adiknya Haryo Suman. Belum sampai lama berbicara disahutlah Haryo Suman dipukuli oleh Patih Gandamana sampai patah tulangnya hingga ca- cat tubuhnya. 5) Tahap Peleraian, konflik yang telah mencapai klimaks diberi penyelesaian, ketegangan dikendorkan konflik-konflik yang lain, sub-konflik atau konflik-konflik tambahan, jika ada juga diberi jalan keluar dan cerita diakhiri. Tahap peleraian pertama diawali ketika Dewi Gendari menemui Prabu Pandhu ,mengatakan mementingkan saudara atau patih. Peleraian beriktnya terjadi ketika surat yang sudah dirubah oleh Haryo Suman dikembalikan pada Prabu Pandhu dan dijelaskan kalau surat tadi diubah oleh Haryo Suman supaya terjadi congkrah antara Prabu Pandu dan Prabu Kala Trembaka.

\section{Latar atau setting}

Latar atau setting merupakan tempat terjadinya kejadian-kejadian yang diceritakan oleh pengarang. Latar juga berfungsi untuk menghidupkan suatu cerita dan untuk membawa pembaca kepada keadaan yang dilukiskan pengarang, latar dapat berupa 1) Latar tempat, disini dimaksudkan adalah untuk mengetahui tempat terjadinya kejadian yang diceritakan 
oleh pengarang atau dalam penelitian ini seorang sutradara. Tempat kejadian atau peristiwa yang terjadi pada lakon Gandamana Luweng adalah sebagai berikut: Negara Ngastina, Negara Pringgodani, Kadipaten Gajah Hoya, sumur atau luweng. 2) Latar waktu, yang terdapat dalam lakon Gandamana Luweng yang sering digunakan adalah keterangan waktu seperti pengguna kata penunjuk waktu yang telah berlalu atau lampau seperti: telung pasewakan iki, kemudian penggunaan keterangan waktu sekarang seperti jaman saiki, dan penggunaan keterangan waktu yang akan datang atau belum terjadi seperti sesuk.

\section{Tema}

Setelah menganalisis lakon wayang Gandamana Luweng, maka dapat diambil simpulan bahwa tema yang diambil adalah perjuangan. Dimana Patih Gandamana menghadapi lika-liku dalam hidupnya untuk berjuang menegakkan kebenaran tak peduli siapapun pasti dimusnahkan, entah itu musuh atau saudara.

\section{Makna Simbolik Lakon Gandamana Luweng}

Semiotik atau ada yang menyebut dengan semiotika berasal dari kata Yunani semeion yang berarti "tanda". Istilah semeion tampaknya diturunkan dari kedokteran hipokratik atau asklepiadik dengan perhatiannya pada simtomatologi dan diagnostik inferensial (Sobur, 2004:95). Secara terminologis, semiotik adalah cabang ilmu yang berurusan dengan dengan pengkajian tanda dan segala sesuatu yang berhubungan dengan tanda, seperti sistem tanda dan proses yang berlaku bagi tanda (van Zoest, 1993:1). Lakon Gandamana Luweng ini meliputi pemaknaan semiotika menyangkut aspek budaya, adat-istiadat atau kebiasaan masyarakat. Oleh karena itu penulis mengkaji makna yang terkandung dalam lakon menggunakan teori semiotika bagian semantic yang berkenaan dengan makna dan konsep. Semantik sendiri terbagi menjadi beberapa bagian salah satunya semantik simbolik, yaitu suatu simbolisasi yang memiliki makna atau pesan tertentu.

Makna adalah pengertian yang diberikan kepada suatu bentuk kebahasaan. Makna merupakan arti atau maksud (sesuatu kata) (Poerwardarminta, 1976:624). Simbol adalah sesuatu yang telah memiliki kesatuan bentuk dan makna. Dalam Kamus Umum Bahasa Indonesia karangan WJS Poerwardaminta disebutkan, simbol atau lambang adalah semacam tanda,lukisan, perkataan, lencana, dan sebagainya yang menyatakan suatu hal, atau mengandung maksud tertentu. Simbol tidak dapat disikapi secara isolatif, terpisah dari hubungan asosiatifnya dengan simbol lainnya. Walaupun demikian berbeda dengan bunyi, simbol telah memiliki kesatuan bentuk dan makna. Berbeda pula dengan tanda (sign), simbol merupakan kata atau sesuatu yang bisa dianalogikan sebagai kata yang telah berkait dengan (1) penafsiran pemakai, (2) kaidah pemakaian sesuai dengan jenis wacananya dan, (3) kreasi pemberian makna sesuai dengan intensi pemakainya. Simbol yang ada dalam dan berkaitan dengan ketiga butir tersebut disebut bentuk simbolik.

Dari beberapa pengertian diatas, penulis menegaskan istilah makna simbolik dalam penelitian ini adalah maksud atau makna yang terkandung dalam suatu simbol atau perlambang terkait dengan pertunjukn wayang kulit lakon Gandamana Luweng. Lakon Gandamana Luweng memiliki makna simbolik yang tersirat atau tidak terungkap secara langsung dalam isi cerita. Dalam pembahasan isi cerita yang telah diungkap pada bab sebelumnya, menunjukkan lakon Gandamana Luweng ini memiliki makna bahwa jika dalam suatu Negara para rakyatnya bermoral lemah tidak mempunyai kekuatan dan keberanian apalagi kesadaran apa arti hidup ini maka hancurlah Negara itu. Karena keberhasilan suatu Negara di masa depan tergantung rakyatnya mengertahui tentang arti hidup. Jika para rakyat tidak memperbaiki moralnya, dan mau belajar dari kesalahan apalagi bersikap tamak, kalau sudah begini sumbangan apa yang akan diberikan terhadap Negara ini.

\section{SIMPULAN}

Lakon Gandamana Luweng memiliki struktur lakon cukup menarik yang dikemas dalam durasi tampilan 60 menit dan mengandung makna bahwa jika dalam suatu Negara para rakyatnya bermoral lemah tidak mempunyai kekuatan dan keberanian apalagi kesadaran apa arti hidup ini maka hancurlah Negara itu. Dengan adanya lakon wayang Gandamana Luweng ini diharapkan para pelaku hidup ini akan sadar tentang pentingnya saling mengerti, menyadari tentang hidup dan kehidupan di dunia ini, sebagai benteng kekuatan untuk memperkokoh Negara dalam menghadapi tantangan apapun.

\section{DAFTAR RUJUKAN}

Creswell, John W. 2015. Penelitian Kualitatif \& Desain Riset: Memilih Di Antara Lima Pendekatan. Yogyakarta: Pustaka Pelajar

Djelantik. 1992. Pengantar Dasar Ilmu Estetika Jilid II: Falsafah Keindahan dan Kesenian. Denpasar: STSI Denpasar

Jones, Pip. 2016. Pengantar Teori-Teori Sosial. Jakarta: Yayasan Pustakan Obor Indonesia

Muelder Eaton, Marcia. 2010. Persoalan-Persoalan 
Dasar Estetika. Jakarta: Salemba Humanika

Nurgiantoro, B. 2002. Teori Pengkajian Fiksi. Yogyakarta: Gadjah Mada University Press.

Poerwadarminta. 1976. Kamus Umum Bahasa Indonesia. Jakarta : Balai Pustaka

Van Zoest, Aart. 1993. Semiotika: Tentang Tanda, Cara Kerjanya dan Apa yang kita Lakukan Dengannya. Jakarta: Yayasan Sumber Agung

Rohidi, Tjetjep Rohendi. 2011. Metodologi Penelitian Seni. Semarang: Cita Prima Nusantara

Sobur, Alex. 2004. Analisis Teks Media. Bandung: Remaja Rosdakarya

Sumaryono. 2007. Jejak dan Problematika Seni Pertunjukan Kita. Yogyakarya: Prasista

Surwedi. 2014. Jaman Antaraboga Layang Kandha Kelir: Kumpulan Lakon Wayang Kulit Purwa Jawa Timuran. Yogyakarta: Buku Litera

Titien Martina, Ria. 2013. "Struktur Lakon Wayang Cekel Endralaya Karya R.M. Ismangun Danuwinata dan Ratnawati Rachmat". Jurnal (diterbitkan). Semarang: FBS UNNES 